
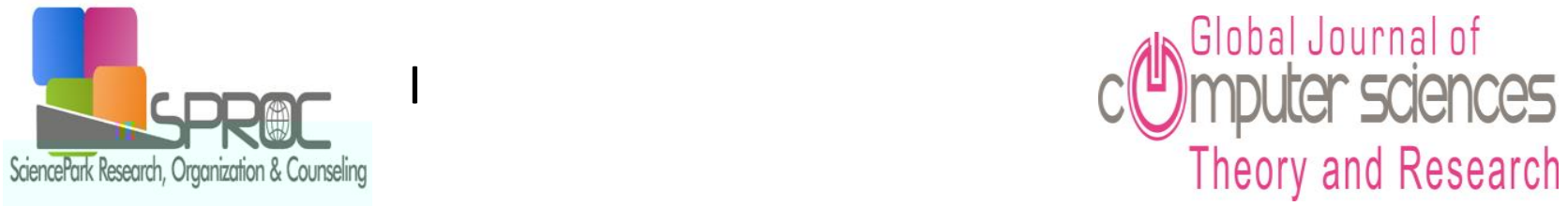

www.gjcs.eu

\title{
Gender differences in computer-related achievement, anxiety and attitude: A meta-analysis in Turkey sample
}

Esad Esgin *

Mehmet Elibol,

Muhammed Daglı,

Suggested Citation:

I

Global Journal of Computer Sciences: Theory and Research 6

Abstract

M 
Global Journal of Computer Sciences: Theory and Research 6

\section{Introduction}

\subsection{Computer Achievement}

1.2. Computer Anxiety

\subsection{Computer-Related Attitude}

1.4. The Study on Computer Achievement, Computer Anxiety and Computer-Related Attitude 


\section{Method}

\section{Implementation of Meta-Analysis}

\subsection{Data Collection}

3.2. Inclusion and Exclusion Criteria

3.3. Coding Method 
Global Journal of Computer Sciences: Theory and Research 6

\subsection{Data Analysis}

\section{Findings}


Global Journal of Computer Sciences: Theory and Research 6 
I

Global Journal of Computer Sciences: Theory and Research 6

5. Discussion and Conclusion 


\section{References}

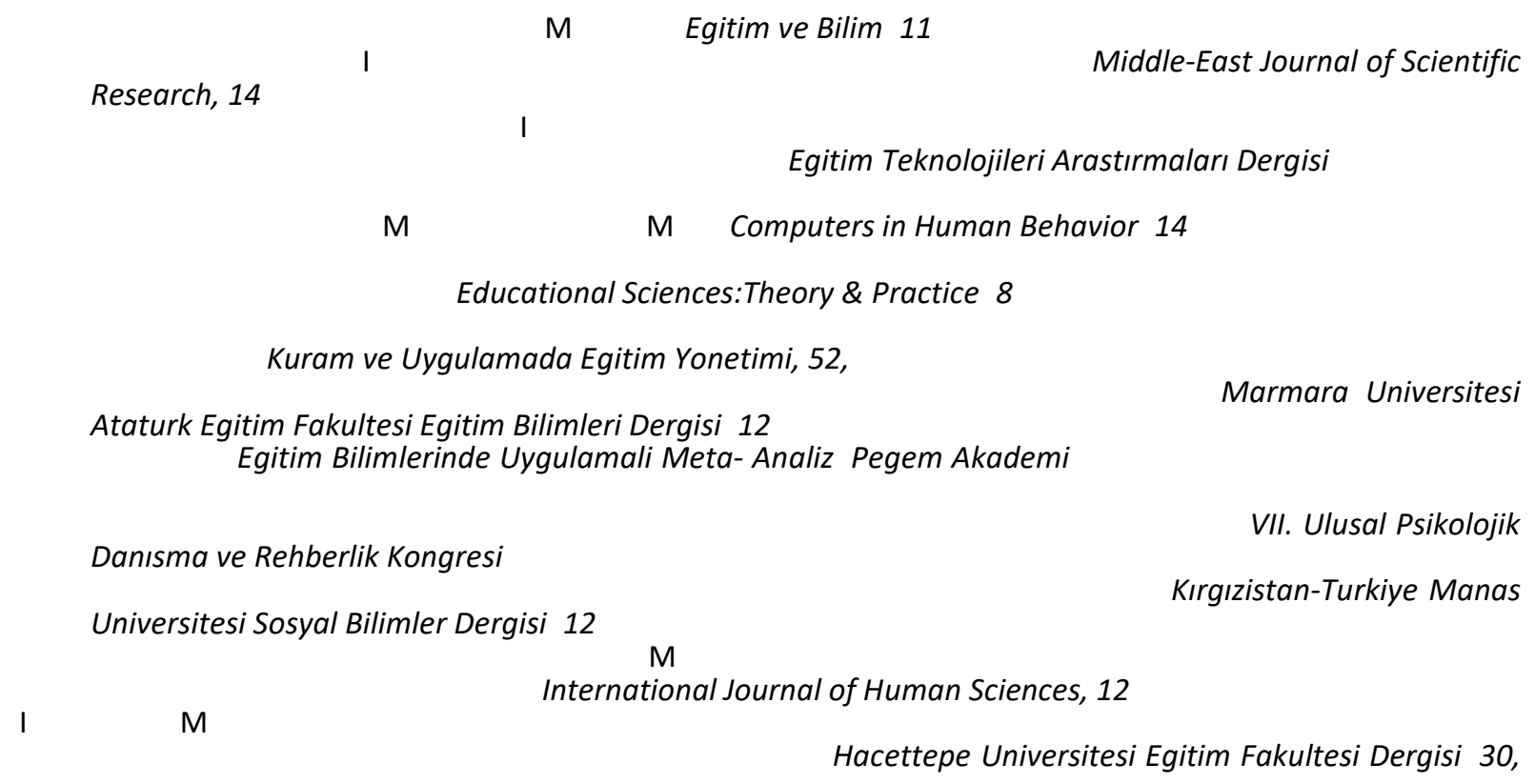

M

M

M Educational Computing Research

Kuram ve Uygulamada Egitim Bilimleri,

instruction

$M$

M I

Technology 28

Computers in human behavior 14

Journal of Technology and Teacher Education 12
Learning and

M

\section{Journal of}

M

Educational

Educational Computing Research, 4

Journal of 
Hacettepe Universitesi Egitim Fakultesi Dergisi 38 I

Computers in human behavior 17

International Journal of Science and Mathematics Education 8

M I

Work-Learning Research

M Journal of Educational Computing Research 28

M

Computers in Human Behavior 13

Verilerin degerlendirilmesinde meta analizi. 